\title{
Microscopic Features, Antioxidant and Antibacterial Capacities of Plants of the Congolese Cosmetopoeia, Raw Materials of Cosmeceuticals
}

\author{
Isaac Kaba Elaka ${ }^{*}$, Paulin Mutwale Kapepula ${ }^{* \#, ~ N a d e ̀ g e ~ K a b a m b a ~ N g o m b e 1, ~}$ \\ Jonathan Mukanya Mpoyi', Dorcas Mukundi Lukusa', Messie Muipata Muabilwa1, \\ Carmel Kandhe Gabha'Bey1, Cyprien Mbundu Lukukula², Boniface Nlandu Lukebakio3, \\ Monique Kandolo Okuna4, Didi Mana Kialengila5, Paul Tshilumbu Kantola²
}

\footnotetext{
${ }^{1}$ Centre d'Etudes des Substances Naturelles d'Origine Végétale (CESNOV), Faculty of Pharmaceutical Sciences, University of Kinshasa, Kinshasa, Democratic Republic of Congo

${ }^{2}$ Laboratory of Experimental and Pharmaceutical Microbiology, Faculty of Pharmaceutical Sciences, University of Kinshasa, Kinshasa, Democratic Republic of Congo

${ }^{3}$ Institut National d'Etudes et de Recherches en Agronomie (INERA), University of Kinshasa, Kinshasa, Democratic Republic of Congo

${ }^{4}$ Bolimo SARL, Kinshasa, Democratic Republic of Congo

${ }^{5}$ Laboratory of Drug Analysis, Faculty of Pharmaceutical Sciences, University of Kinshasa, Kinshasa, Democratic Republic of Congo

Email: "garaphmutwal@yahoo.fr
}

How to cite this paper: Elaka, I.K., Kapepula, P.M., Ngombe, N.K., Mpoyi, J.M., Lukusa, D.M., Muabilwa, M.M., Gabha'Bey, C.K., Lukukula, C.M., Lukebakio, B.N., Okuna, M.K., Kialengila, D.M. and Kantola, P.T. (2020) Microscopic Features, Antioxidant and Antibacterial Capacities of Plants of the Congolese Cosmetopoeia, Raw Materials of Cosmeceuticals. Journal of Biosciences and Medicines, 8, 149-166.

https://doi.org/10.4236/jbm.2020.89013

Received: August 14, 2020 Accepted: September 14, 2020 Published: September 17, 2020

\begin{abstract}
Cosmeceuticals are the fastest growing products in the cosmetics field and represent a hybrid between cosmetics and drugs. The main benefits reported for cosmeceutical herbal extracts, used in skin care, include antioxidant and antimicrobial activities and the tyrosinase inhibiting effect. The aim of this study was to evaluate the antioxidant and antibacterial activities of extracts from Chromolaena odorata, Mitracarpus villosus, Senna alata, Tetradenia riparia, Cannabis sativa and Pterocarpus soyauxii used traditionally in the management of skin and skin annexes pathologies; additionally to determine their microscopical characteristics and their chromatographic fingerprints. Microscopic analyses showed the specific botanical microscopic characters for each plant that constitute the database useful for the identification and authentication of these botanicals. To the best of our knowledge, our work is the first to describe the microscopic histological characters of studied plants except for Cannabis sativa. The results of the TLC chromatographic analysis
\end{abstract}


Copyright (c) 2020 by author(s) and Scientific Research Publishing Inc. This work is licensed under the Creative Commons Attribution International License (CC BY 4.0).

http://creativecommons.org/licenses/by/4.0/ (c) (i) Open Access revealed the richness in phenolic compounds, terpenes in all extracts and Pterocarpus soyauxii contained coumarins. All extracts displayed high ABTS and DPPH radical-scavenging activities connected with their $\mathrm{IC}_{50}$ values at the concentration range of $1-125 \mu \mathrm{g} / \mathrm{mL}$ with Cannabis sativa and Pterocarpus soyauxii as the most active. All plant extracts exhibited antibacterial activity on Escherichia coli, Pseudomonas aeruginosa and Staphylococcus aureus to varying degrees. Cannabis sativa exhibited strong effect on Staphylococcus aureus and Escherichia coli. Chromolaena odorata and Tetradenia riparia showed a marked effect on Escherichia coli. Although certain crude extracts from studied botanicals have been shown to be inactive, fractionation studies are needed to determine the active fractions. Obtained biological activities could be related to phytochemicals present in the organic extracts like phenolic compounds and terpenoids. The antioxidant and antibacterial activities of the studied species may have potential therapeutic interest and could justify their use in traditional medicine and local cosmeceutical resources, but further studies are needed, especially in vivo studies, to demonstrate the benefit of these extracts on skin and skin appendages care.

\section{Keywords}

Cannabis sativa, Chromolaena odorata, Cosmeceuticals, Cosmetopoeia, Mitracarpus villosus, Pterocarpus soyauxii, Senna alata, Tetradenia riparia, Yelena

\section{Introduction}

Cosmeceuticals are the fastest growing products in the cosmetics field [1]. Consequently, their future is very promising [2]. A cosmeceutical is an intermediary between a cosmetic and a drug, having pharmaceutically active compounds affecting a cosmetic improvement by a physiological action on the skin. This new concept represents a hybrid between cosmetics "cosme-" and drugs "-ceutical" [3]. Cosmeceuticals can thus be used for both therapeutic and aesthetic purposes [4]. The impact of cosmeceuticals on humanity will be greater than ever [2]. Nowadays, plant extracts used as ingredients that support the health, texture and integrity of the skin, hair and nails are widely used in cosmetic formulations. They constitute the largest category of cosmeceutical additives present on the market due to the growing interest of consumers and the demand for natural products [5]. They are still very popular in the current community [4] and the popular uses of plants for cosmetic or dermatological purposes have always existed in many countries and cultures of the world [6]. The valorization of this heritage suffers from a lack of precise knowledge on the chemical nature and the biological characteristics of its plants' extracts [7] although the natural ingredients used are spreading more and more as cosmeceuticals, due to the concerns of consumers about synthetic ingredients that are less reassuring and excessively 
expensive [8].

The Democratic Republic of the Congo (DR Congo) is a country of great biological diversity (flora and fauna) and these natural products should therefore be upgraded so that they can also serve the entire rural population. The cosmetopoeia concerns the collection of plants used in cosmetics and their traditional uses. It is an innovative concept, which should be developed due to the fact that currently this subject is very almost not documented and the writings are little available. Cosmetopoeia is to cosmetics what pharmacopoeia is to pharmacy, constituting an encyclopedia of plants and their traditional uses intended to maintain health or care [6]. It aims to promote and safeguard biodiversity and traditional knowledge by carrying out an inventory of existing cosmetic plants before they disappear [7]. While the pharmacopoeia that lists plants for therapeutic purposes has experienced considerable development for a long time, work in the field of cosmetopoeia products is still little documented in the literature [9]. The skin considered as the body's largest organ is the main barrier of the body against the external environment. Human skin infections, especially those involving soft skin and mucous surfaces, are a serious problem, especially in tropical and subtropical Low-Income Countries [10]. The most common skin pathogens are methicillin resistant Staphylococcus aureus (MRSA), Staphylococcus epidermidis, Escherichia coli, Pseudomonas aeruginosa and Candida albicans [11]. In some Asian and African countries, up to $80 \%$ of the population relies on traditional medicine for their primary health care needs and in the DR Congo, several plants are traditionally used for the management of skin and skin appendages pathologies. World Health Organization (WHO) recognizes that traditional, complementary and alternative medicine has many benefits and Africa has a long history of traditional medicine and practitioners that play an important role in providing care to populations [12]. Then assessing and guaranteeing their safety and efficacy such as herbal cosmeceuticals constitutes an important challenge. In addition, the main benefits reported for cosmeceutical herbal extracts, used in skin care, include antioxidant and antimicrobial activities and the tyrosinase inhibiting effect [8]. The aim of this study was to evaluate the antioxidant and antibacterial activities of extracts from leaves of Chromolaena odorata (L.) R. King \& H. Rob., Mitracarpus villosus (Sw.) DC., Senna alata (L.) Roxb., Tetradenia riparia (Hochst.) Codd, flowering tops of Cannabis sativa L. and red wood powders (trunk) of Pterocarpus soyauxii Taub. (Figure 1, Table 1) used in the Congolese cosmetopoeia as natural cosmeceuticals agents. Additionally, to better characterize the different parts of plants investigated, their microscopical characteristics and their chromatographic fingerprints were determined.

\section{Material and Methods}

\subsection{Material}

Flowering tops, leaves and the trunk samples of the plant species harvested from different places of Kongo Central, Equateur and Kinshasa provincial city, were 


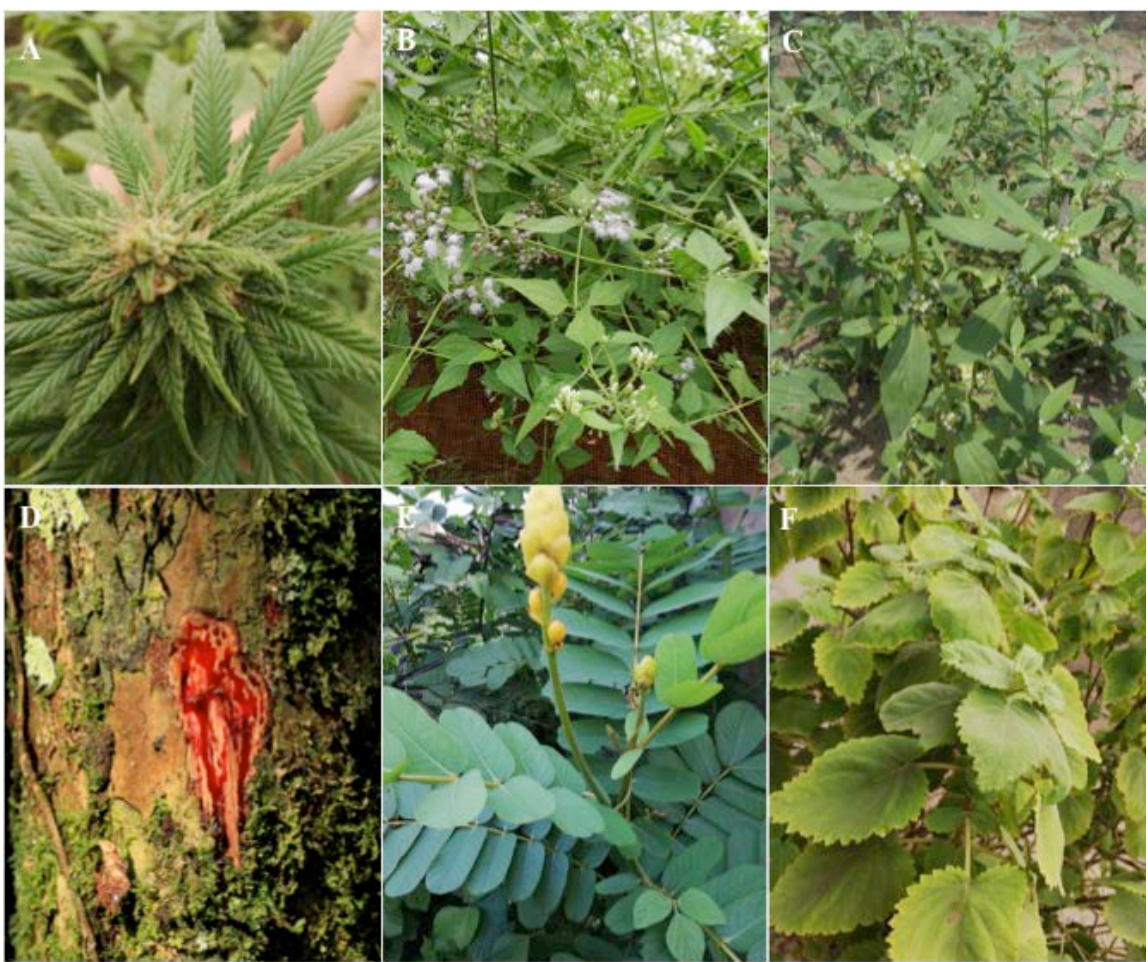

Figure 1. Studied plants (A) Cannabis sativa L., (B) Chromolaena odorata (L.) R. King \& H. Rob., (C) Mitracarpus villosus (Sw.) DC., (D) Pterocarpus soyauxii, (E) Senna (Cassia) alata (L.) Roxb., (F) Tetradenia riparia (Hochst.) Codd.

Table 1. Selected plants species used for treatment of skin pathologies and skin appendages care.

\begin{tabular}{|c|c|c|c|c|}
\hline Plant species (Family) & $\begin{array}{c}\text { Congolese } \\
\text { Vernacular names }\end{array}$ & Part of plant & $\begin{array}{c}\text { Congolese } \\
\text { Traditional uses }\end{array}$ & Places of collection \\
\hline $\begin{array}{l}\text { Cannabis sativa } \\
\text { (Cannabaceae) }\end{array}$ & Bangi, Diamba & Flowering tops & $\begin{array}{c}\text { Measles enema with the } \\
\text { maceration of the leaves } \\
{[13][14]}\end{array}$ & Kisantu/Kongo Central \\
\hline $\begin{array}{l}\text { Chromolaena odorata } \\
\text { (Asteraceae) }\end{array}$ & Apollo & Leaves & Conjontivite [14] & Mont Ngafula/Kinshasa \\
\hline $\begin{array}{l}\text { Mitracarpus villosus } \\
\quad \text { (Rubiaceae) }\end{array}$ & $\begin{array}{l}\text { Banda nzazi, } \\
\text { Bana ba nzazi }\end{array}$ & Aerial parts & $\begin{array}{c}\text { Fungal skin infections and } \\
\text { eruptions, herpes, skin } \\
\text { mycosis and ringworm } \\
\text { eczema and stubborn } \\
\text { ulcers [13] }\end{array}$ & University of Kinshasa \\
\hline $\begin{array}{c}\text { Pterocarpus soyauxii } \\
\text { Fabaceae }\end{array}$ & Ngola & Trunk (Red wood) & $\begin{array}{l}\text { Skin pathologies }[14] \\
\text { Scar, Skin and Hair } \\
\text { coloration }[6]\end{array}$ & Province of Equateur \\
\hline Senna alata (Fabaceae) & Bwalu, bawubawu & Leaves & $\begin{array}{l}\text { Fungal skin } \\
\text { infections [14] }\end{array}$ & Ngaba/Kinshasa \\
\hline $\begin{array}{l}\text { Tetradenia riparia } \\
\text { (Lamiaceae) }\end{array}$ & $\begin{array}{c}\text { Mutuzo, Mutizo, } \\
\text { Mushubya }\end{array}$ & Leaves & $\begin{array}{l}\text { An antiseptic to treat } \\
\text { wounds [15] }\end{array}$ & Mont Ngafula/Kinshasa \\
\hline
\end{tabular}


air-dried at room temperature. The plants were identified by Boniface Nlandu of the Institut National d'Etudes et de Recherches en Agronomie (INERA), University of Kinshasa, Kinshasa, Democratic Republic of Congo. Prior to extraction, flowering tops, leaves and trunk were ground and stored in brown covered glass bottles.

\subsection{Chemicals and Reagents}

Analytical and HPLC grade solvents used were purchased from Merck VWR (Leuven, Belgium). 1,1-Diphenyl-2-picrylhydrazyl (DPPH), 2,2'-Azino-bis(3-ethylBenz-Thiazoline-6-Sulfonic) acid (ABTS), 2-aminoethyl diphenylborinate, Anisaldehyde and potassium persulfate were purchased from Sigma (Bornem, Belgium).

Caffeic acid, Chlorogenic acid (purity: 95\%), Gallic acid (purity: 97\%) was purchased from Sigma-Aldrich. Rutin (purity: 99\%), isoquercitrin (purity: 99\%) and, quercetin (purity: 98.5\%) were HPLC grade and purchased from Extrasynthese.

\subsection{Microscopic Analysis}

Powder observations were made using European Pharmacopeae reagent, the lactic acid reagent (Steimetz reagent) [16]. Observations were made with a VisiScope BL124 (VWR) microscope, and pictures were taken with Smart Phone Samsung S9.

\subsection{Preparation of Extracts}

Organic extracts were prepared by percolation of $10 \mathrm{~g}$ of sample powders with $150 \mathrm{~mL}$ of mixture dichloromethane and methanol (1:1). Evaporation of the solvents was performed under reduced pressure $\left(\right.$ at $\left.40^{\circ} \mathrm{C}\right)$ and the extracts were then weighed and kept in dark hermetic flasks at $4^{\circ} \mathrm{C}$.

\subsection{Phytochemical Analysis}

Thin Layer Chromatography (TLC) Analysis

Analytical TLC of $10 \mu \mathrm{L}$ of solution for $10 \mathrm{mg} / \mathrm{mL}$ of dichloromethane and methanolic extracts was carried out on normal phase Silica gel $60 \mathrm{~F}_{254}$ plates (Merck), using different eluents for the identification of secondary metabolites [17].

\subsection{Cell Free Antioxidant Assays}

The extracts were solubilized in methanol, thus their effect was compared to a control test performed with methanol alone. Antioxidant activity was assayed through spectrophotometric ABTS and DPPH that were performed according to the method described by Kapepula et al. (2018) [18].

\subsection{Antibacterial Activity}

The antibacterial activity was evaluated using the microdilution method on 
96-well sterile polystyrene microplates and in liquid medium as previously reported [19]. The extract to be tested ( $20 \mathrm{mg}$ ) is dissolved in $250 \mu \mathrm{L}$ of dimethysulfoxide (DMSO) and the final volume is adjusted to $5 \mathrm{~mL}$ with Mueller Hinton culture medium. The bacterial suspension is prepared by adding in $2 \mathrm{~mL}$ of saline solution $(0.9 \% \mathrm{NaCl})$ for each strain, three colonies isolated from strains to be tested (Staphylococcus aureus ATCC 25923, Escherichia coli ATCC25922 and Pseudomonas aeruginosa ATCC 9027) and a $24 \mathrm{~h}$ incubation allowed to obtain $0.5 \mathrm{McF}$ arland $\left(10^{6}\right.$ cells $\left./ \mathrm{mL}\right)$. Therefore, the bacterial suspension is diluted in order to have $10^{6}$ cells $/ \mathrm{mL}$ (1:100 dilution). The microdilution assay was performed in a 96-well sterile polystyrene microplate. Briefly, $100 \mu \mathrm{L}$ of culture medium were placed inside wells. After, $200 \mathrm{uL}$ of each extract to be tested (1000 $\mu \mathrm{g} / \mathrm{mL}$ ) were placed in wells. Thus, take $100 \mu \mathrm{L}$ of each extract stock solution for serial dilutions of 2 to 2 up to the ninth column and the last $100 \mu \mathrm{L}$ (column 9) are removed. $5 \mu \mathrm{L}$ of the inoculum $\left(10^{8} \mathrm{CFU} / \mathrm{mL}\right)$ are aseptically removed with a micropipette and added to all wells of the microplate except for wells of the $11^{\text {th }}$ column used as control for the bacterial growth and wells of the $12^{\text {th }}$ column, which were used as control of sterility of culture medium. Microplates were incubated in an oven at $37^{\circ} \mathrm{C}$ for 24 hours. After the incubation period, $3 \mu \mathrm{L}$ of Resazurin dye (1\%) was added to each well and the microplates were kept for a second incubation for 7 hours. The Minimum Inhibitory Concentration (first wells with no bacterial growth) was determined 24 hours later.

\subsection{Statistical Analysis}

Each concentration was tested in triplicate in each assay, and at least 3 different assays were performed. All results were expressed as mean values \pm standard deviation (SD). The statistical analysis was performed with GraphPad 7.0 (GraphPad Software, San Diego California, USA). Two-way analysis (ANOVA) and Student's paired t-test were used; multiple comparisons of all data were performed using the "Tukey" Multiple Comparisons Test and the level of statistical significance was set at $\mathrm{p}<0.05$. The $\mathrm{IC}_{50}$ values were calculated with GraphPad Prism 7.0 under application of the function "log (inhibitor) vs. normalized response-variable slope" after converting the concentrations into their decimal logarithm.

\section{Results and Discussion}

\subsection{Botanical Microscopic Features}

The sample powders from plants were treated with European Pharmacopeae reagent and showed the following specific botanical microscopic characters for each plant (Table 2 and Figures 2-7).

To the best of our knowledge, there is no existing work which describes the microscopic histological characters of studied plants except for Cannabis sativa. Medicinal plant materials are categorized according to sensory microscopic and macroscopic characteristics. Microscopical inspection of crude drugs of plant 
origin is essential for the identification of ground or powdered materials. Microscopy is useful for the identification and authentication of botanicals and for detecting the adulterated and poor quality [20]. Authentication of herbal materials includes morphological, microscopic, and chemical identification. Adulteration in the plant samples is a serious issue that involves the deliberate or inadvertent mixture of a plant species by other inferior species, plants of other genera, or even toxic materials. Microscopic analysis is one of the cheapest methods to correctly identify the drugs and the raw materials from herbal medicines [20] [21]. The microscopical examination of crude drugs aims to determine the chemical nature of the cell wall along with a determination of the form and chemical nature of the cell contents. Thus, it determines the size, shape, and relative structure of the different cells and tissues in a plant drug [21]. Hence, the knowledge of microscopic details of the studied species is one of the most valuable tools for the evaluation of the quality and identity of these plant species. However, in-depth microscopic examinations should be carried out mainly to determine the dimensions of certain characteristic elements such as size of starch grains, calcium oxalate prisms and length of fibres and sclereids. Though microscopy alone cannot provide a complete evaluation profile of an herbal drug, it can still provide supporting evidence, which, when combined with other analytical parameters such as chromatographic fingerprints, can be used to obtain the full evidence for the standardization and evaluation of herbal drugs [21].

Table 2. Microscopical features of selected plants.

\begin{tabular}{|c|c|c|}
\hline $\mathrm{N}^{\circ}$ & Samples & Microscopical features \\
\hline 1 & $\begin{array}{l}\text { Cannabis } \\
\text { sativa }\end{array}$ & $\begin{array}{l}\text { Detached heads from the multicellular glandular trichomes, oil droplets, upper } \\
\text { epidermis of a bract with a part of the underlying palisade. Upper epidermis } \\
\text { of a bracteole in surface view showing cluster crystals of calcium oxalate, } \\
\text { multicellular, multiseriate glandular trichomes, sclereids, fibrous sclereids, } \\
\text { lower epidermis of a bracteole showing anomocytic stomata, covering } \\
\text { non-cystolithic trichomes, part of a papilla from a stigma, annularly } \\
\text { and reticulately thickened vessels, secretory duct, starches granules }\end{array}$ \\
\hline 2 & $\begin{array}{l}\text { Chromolaena } \\
\text { odorata }\end{array}$ & $\begin{array}{l}\text { Upper epidermis with palisade parenchyma occurring in two cell layers, spongy } \\
\text { mesophyll, sclereids, lower epidermis showing wavy anticlinal cell walls, } \\
\text { scalariform vessels, upper epidermis showing sinuous anticlinal cell walls }\end{array}$ \\
\hline 3 & $\begin{array}{l}\text { Mitracarpus } \\
\text { villosus }\end{array}$ & $\begin{array}{l}\text { Lower epiderm showing anomocytic stomata, unicellular non glandular } \\
\text { trichomes, upper epidermis showing sinuous anticlinal cell walls and } \\
\text { helicoidal vessels and secretory ducts }\end{array}$ \\
\hline 4 & $\begin{array}{l}\text { Pterocarpus } \\
\text { soyauxii }\end{array}$ & $\begin{array}{l}\text { Cork in surface, fibres, part of xylem showing parenchymatous cells, some } \\
\text { containing prisms of calcium oxalate, fragment of parenchyma, } \\
\text { medullary ray, pitted vessels }\end{array}$ \\
\hline 5 & Senna alata & $\begin{array}{l}\text { Lower epidermis showing paracytic stomata, upper epidermis showing } \\
\text { wavy anticlinal cell wall, glandular trichomes and unicellular nonglandular } \\
\text { trichomes, group of fibres with calcium oxalate prism, lower palisade } \\
\text { with spongy mesophyll cells, scalariform vessels }\end{array}$ \\
\hline 6 & $\begin{array}{l}\text { Tetradenia } \\
\text { riparia }\end{array}$ & $\begin{array}{l}\text { Secretory cells, upper epidermis showing wavy anticlinal cell walls, lower } \\
\text { epidermis with diacytic stomata, pluricelluar nonglandular trichomes... }\end{array}$ \\
\hline
\end{tabular}



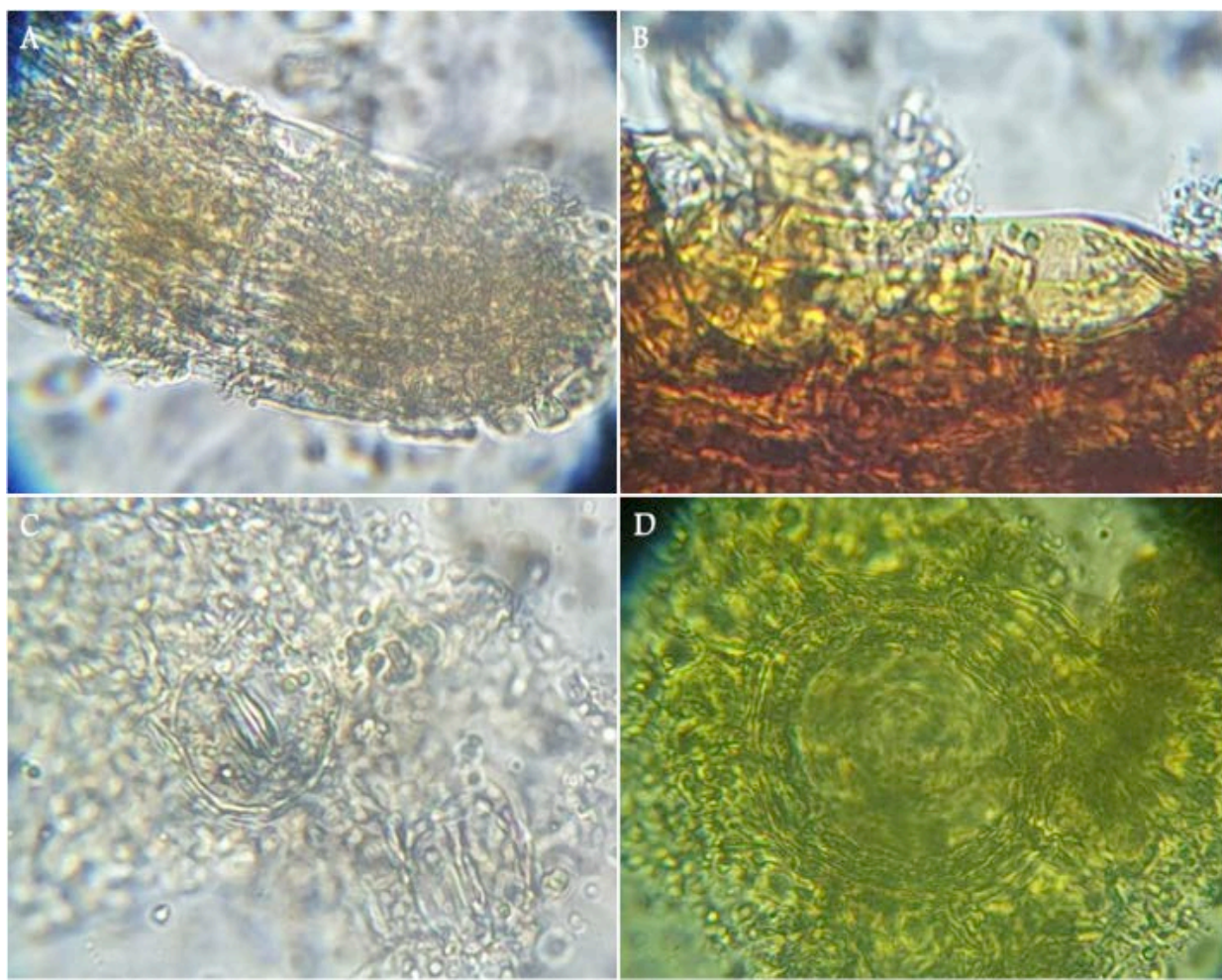

Figure 2. Multicellular, multiseriate glandular trichome (A), sclereids (B), lower epidermis of a bract showing anomocytic stomata (C) and secretory duct of Cannabis sativa (40×).
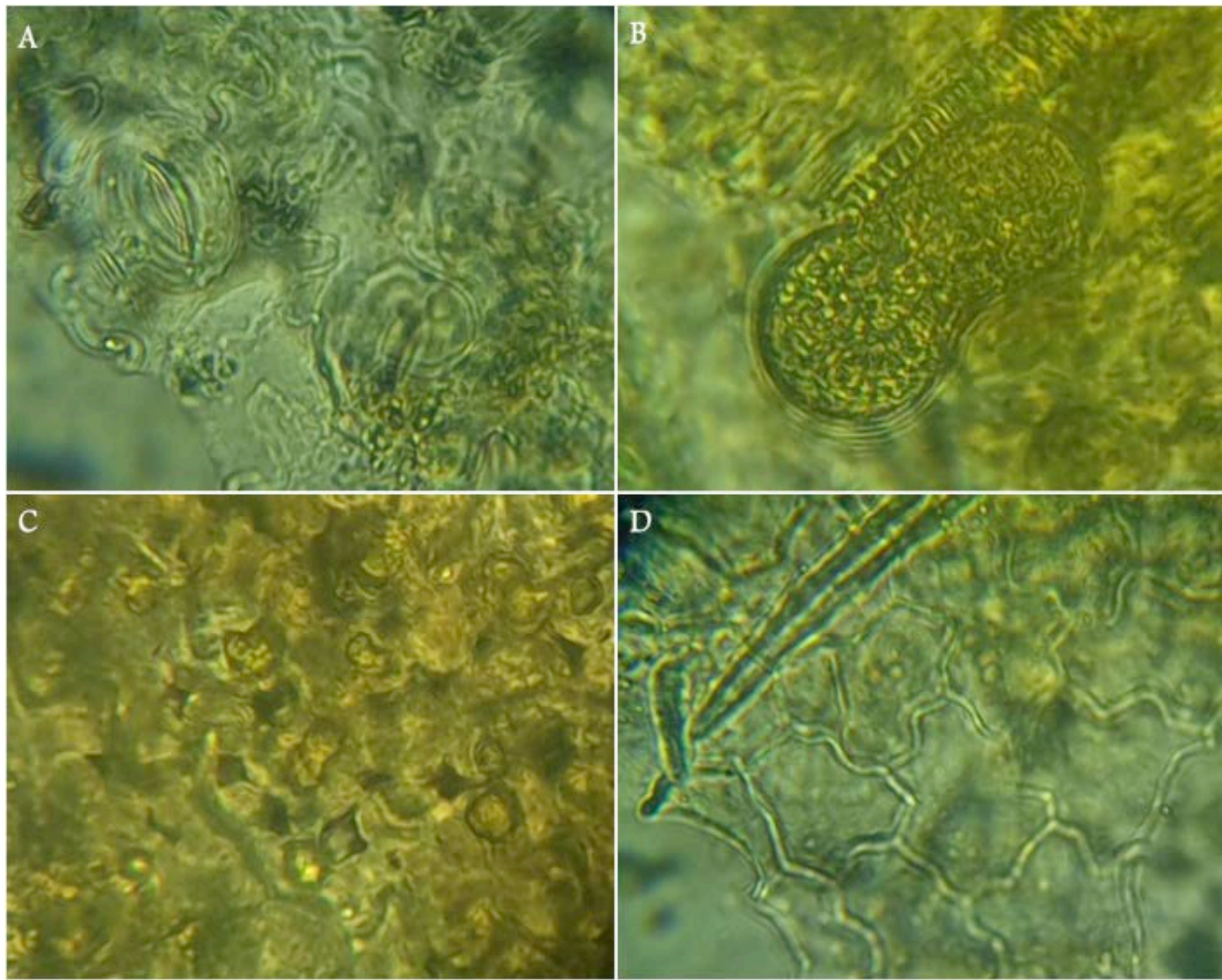

Figure 3. Lower epiderm showing diacytic stomata (A), secretory cell (B), fragment of parenchyme with cluster of calcium oxalate $(\mathrm{C})$, upper epidermis showing sinuous anticlinal cell walls and unicellular non glandular trichomes (D) of Chromolaena odorata (40x). 

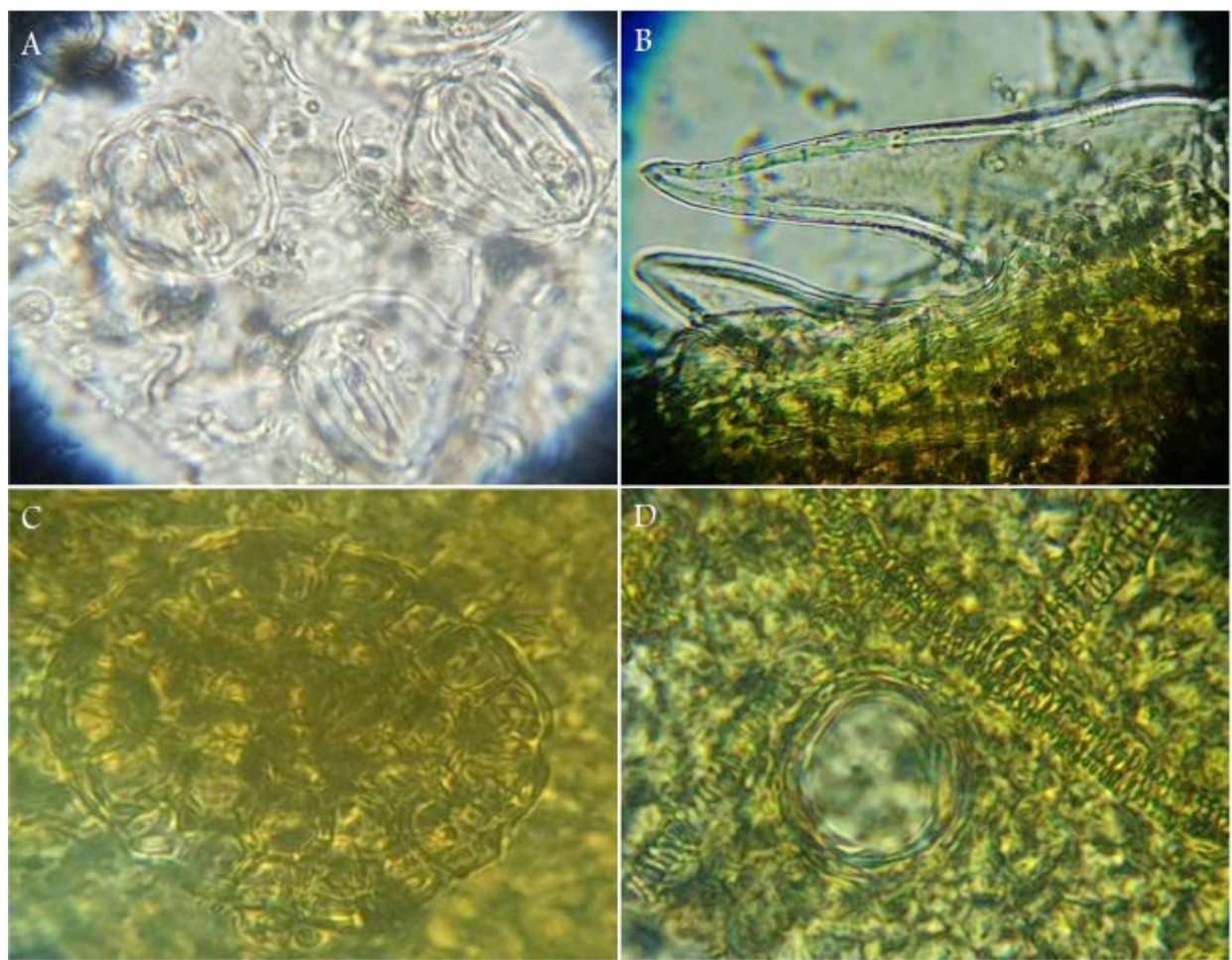

Figure 4. Lower epiderm showing anomocytic stomata (A), unicellular non-glandular trichomes (B), secretory cell (C), upper epidermis showing sinuous anticlinal cell walls and helicolidal vessels and secretory adducts (D) of Mitracarpus villosus (40×).

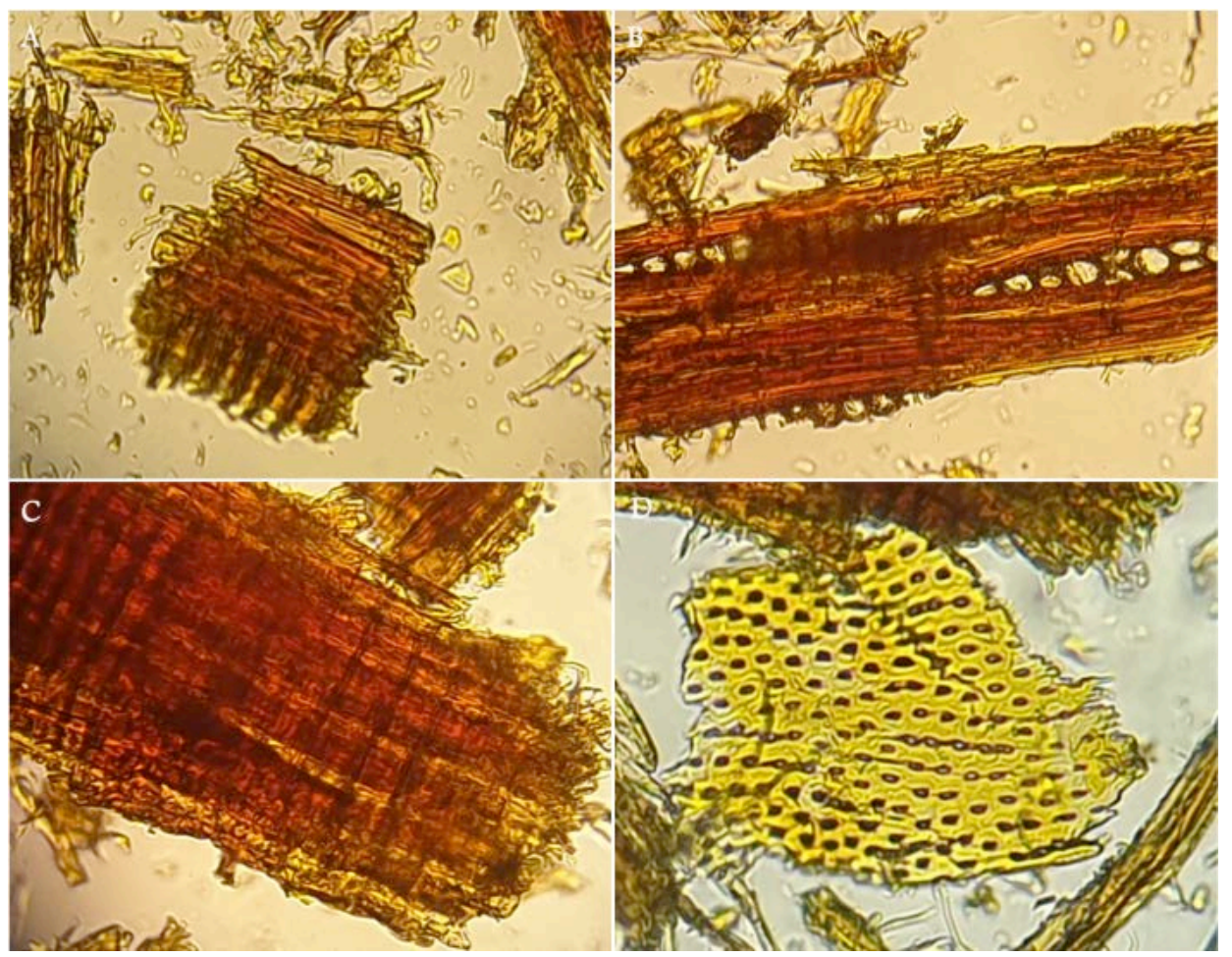

Figure 5. Cork in surface view fibres (A), part of xylem showing parenchymatous cells, group of fibers with prisms of calcium oxalate (B), fragment of parenchyma (C), pitted vessels (D) of Pterocarpus soyauxii (10×). 


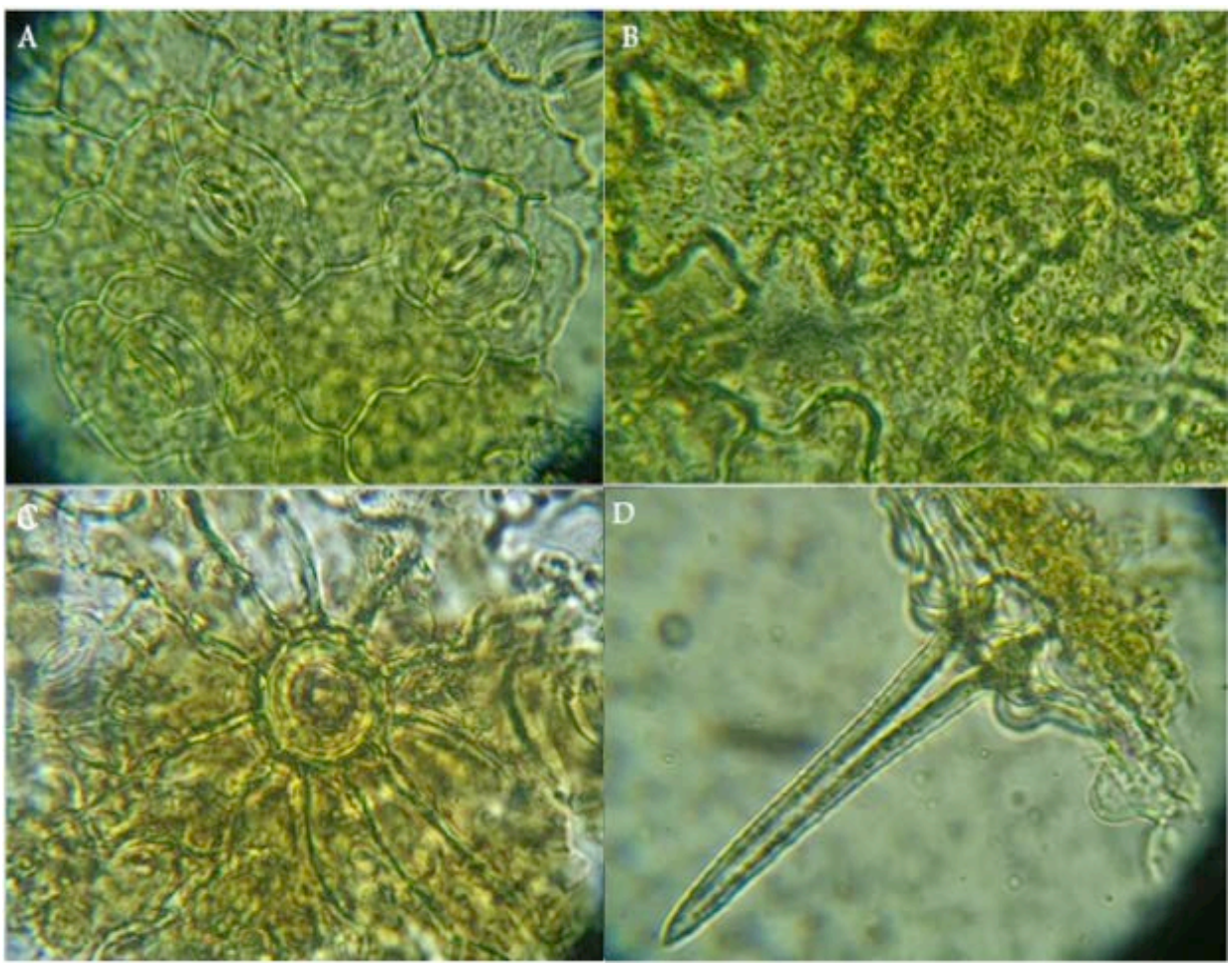

Figure 6. Lower epidermis showing paracytic stomata (A), upper epidermis showing wavy anticlinal cell wall (B), glandular trichomes (C) and unicellular non-glandular trichomes (D) of Senna alata $(40 \times)$.

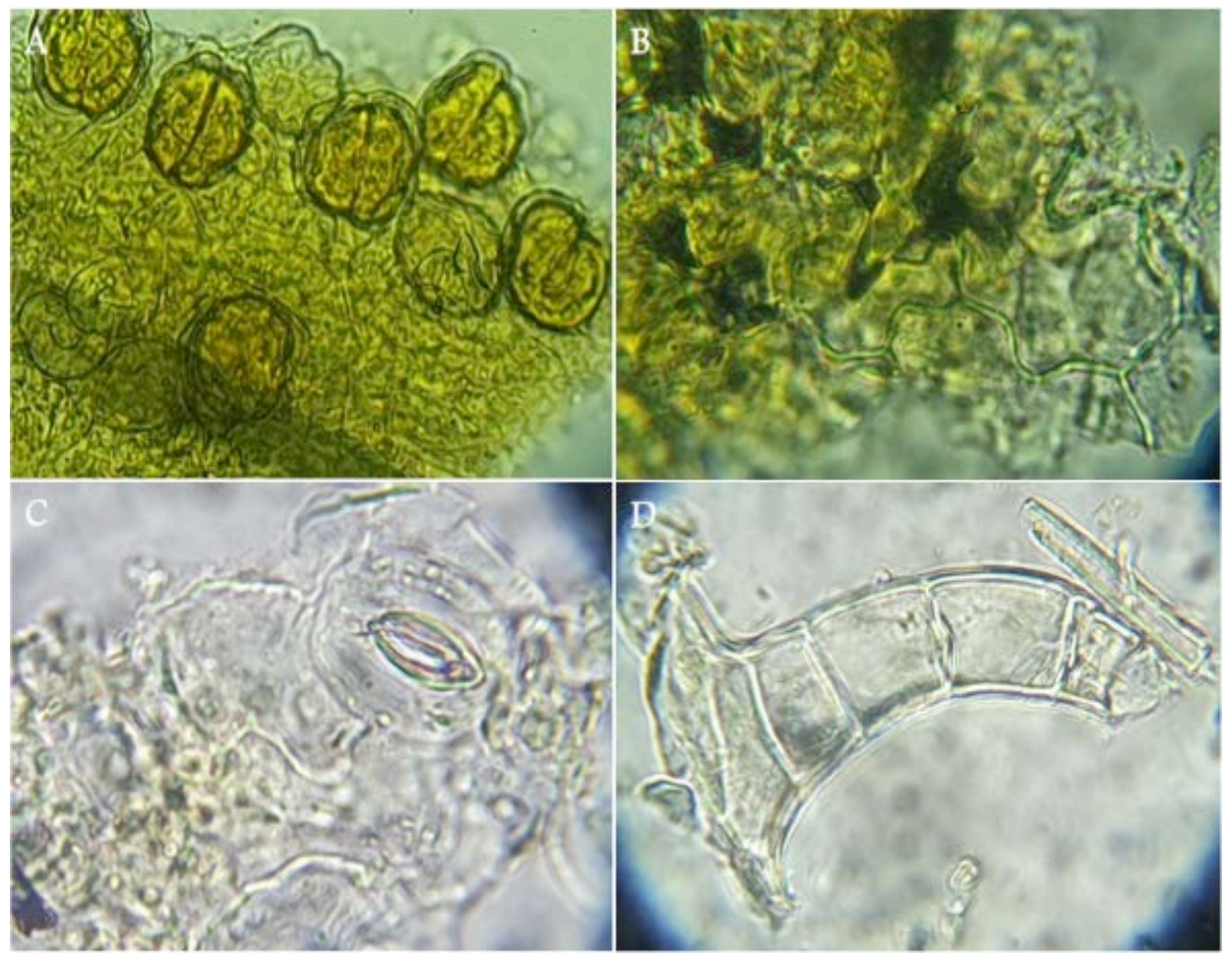

Figure 7. Secretory cells (A), upper epidermis showing wavy anticlinal cell walls (B), lower epidermis with diacytic stomata (C), pluricelluar non-glandular trichomes (D) of Tetradenia riparia $(40 \times)$. 


\subsection{Phytochemicals}

The phytochemical screening by TLC was carried out on methanolic and ethyl acetate extracts of the plants. The results of the TLC chromatographic analysis revealed the richness in phenolic compounds of the different extracts of Tetradenia riparia, Senna alata, Mitracarpus villosus and Pterocarpus soyauxii unlike those of Chromolaena odorata and Cannabis sativa. However, there is a diversity of terpenoids in the various extracts from parts of the plants analysed (Figure 8).

The leaves of Tetradenia riparia and Senna alata contain a large amount of flavonoids compared to those of Mitracarpus villosus. Little or no phenolic acids contained in the leaves of the latter three, however the wood of Pterocarpus soyauxii contains more. Compared to the reference substances used, the leaves of Tetradenia riparia, Senna alata and Mitracarpus villosus would contain flavonoids, which would probably be kaempferol and quercetin derivatives. These data correspond to the results reported in the literature on the chemical composition. They also corroborate those reported by Dewi et al. (2019) which showed that kaempferol derivates (e.g. kaempferol-3-O-gentiobioside and kaempferol-3-O-d-glucopyranoside) have been reported in the leaves of Senna alata [22]. Chromolaena odorata was described to contain polyphenols like flavanone compounds [23]. Previous studies reported the presence of flavonoids in the aqueous and methanolic extracts of Mitracarpus villosus [24]. In addition, the profile of red wood from the trunk of Pterocarpus soyauxii shows only blue fluorescences marking the presence of phenolic acids as reported in the literature [25]. Tannins were found in different analysed plants while Pterocarpus soyauxii

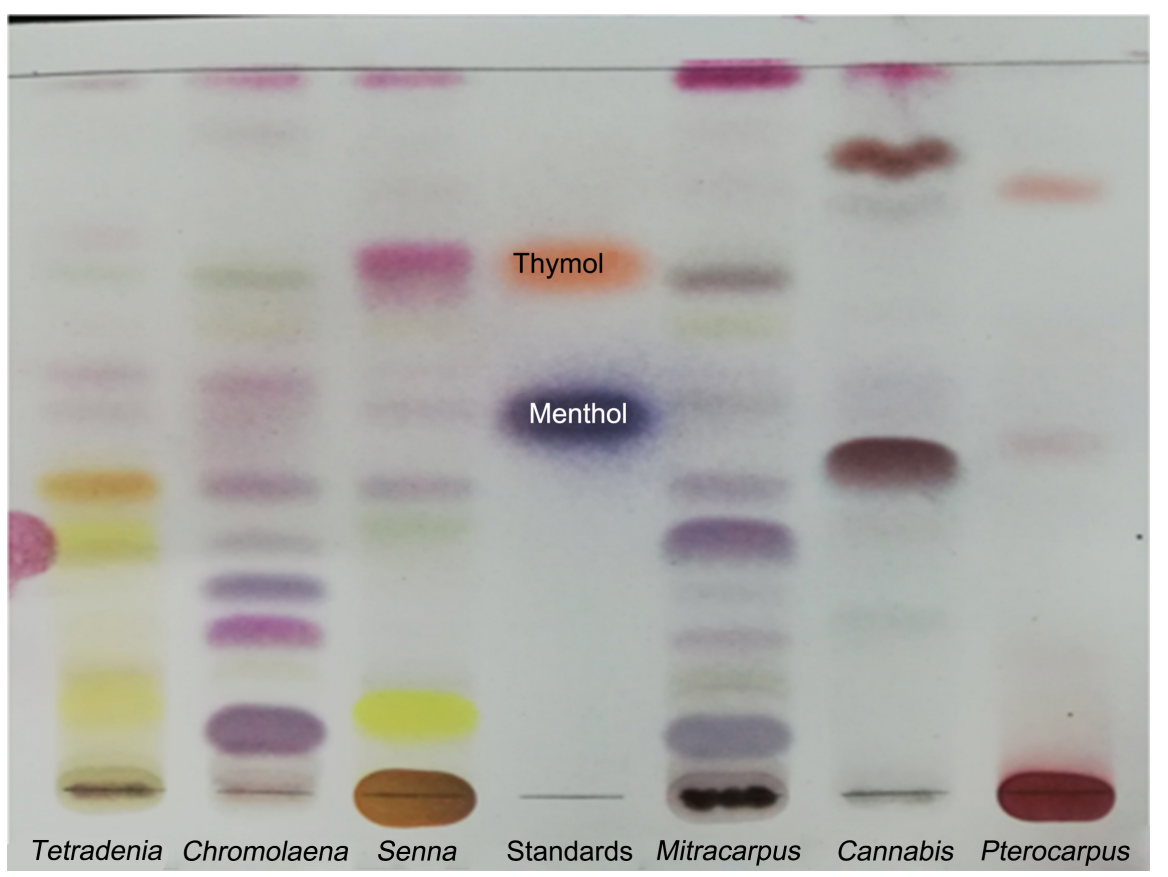

Figure 8. TLC chromatogram of dichloromethane extracts from studied plants with menthol, thymol as standards; developed with toluene/ethyl acetate $(9: 1 ; \mathrm{v} / \mathrm{v})$ and visualized at visible with sulfuric anisaldehyde reagent. Terpenes are detected as violet spots. 
contained catechic tannins. Cannabinoids were identified in flowering tops of Cannabis sativa.

TLC analysis of ethyl acetate extracts revealed the presence of terpenes. Each extract showed a characteristic chromatographic profile. The leaves of Chromolaena odorata, Senna alata, Mitracarpus villosus and Tetradenia riparia contained more terpenes than flowering tops of Cannabis sativa and the red wood of Pterocarpus soyauxii. By comparison with the controls used, we estimate that the leaves of Senna alata and Mitracarpus villosus would contain thymol and Chromolaena odorata would contain oleanolic acid. Coumarins have been found only in the bark of Pterocarpus soyauxii. This difference with the data in the literature could be due to some factors and chemical profile is generally influenced by the harvesting season, the $\mathrm{pH}$ of soils, the choice and stage of drying conditions, the geographic location, chemotype or subspecies, and choice of part plant or genotype or extraction method.

\subsection{Antioxidant Activity}

The evaluation of antioxidant activity using ABTS and DPPH assays showed that all the extracts have shown the ability to inhibit radicals connected with their $\mathrm{IC}_{50}$ values (Table 3 ).

Radical-scavenging activities vary significantly in each type of test. The $\mathrm{IC}_{50}$ values of ABTS assay were weak than those of DPPH assay. This difference is attributed to the reaction mechanisms. Indeed, ABTS reacts simultaneously with hydrophilic and lipophilic compounds while DPPH reacts only with hydrophilic compounds of the analysed matrice. Extracts of Cannabis sativa and Pterocarpus soyauxii showed very low values, which testify to their more powerful scavenging radical effect. The flowering tops of Cannabis sativa were therefore shown to be more active, followed by the red wood of Pterocarpus soyauxii then the leaves

Table 3. $\mathrm{IC}_{50}$ values $(\mu \mathrm{g} / \mathrm{mL})$ of organic extracts of plants on ABTS and DPPH assays $($ Mean $\pm S D, n=6)$.

\begin{tabular}{cccc}
\hline & & & \multicolumn{2}{c}{$\mathrm{CI}_{50}$} \\
$\mathrm{~N}^{\circ}$ & Samples & ABTS $(\mu \mathrm{g} / \mathrm{mL})$ & $\mathrm{DPPH}(\mu \mathrm{g} / \mathrm{mL})$ \\
\cline { 3 - 4 } 1 & Cannabis sativa & $2.75 \pm 0.31$ & $15.21 \pm 1.12$ \\
2 & Chromolaena odorata & $9.75 \pm 2.7$ & $51.5 \pm 12.1$ \\
3 & Mitracarpus villosus & $16.52 \pm 1.22$ & $42.76 \pm 3.48$ \\
5 & Pterocarpus soyauxii & $3.26 \pm 0.28$ & $11.69 \pm 1.43$ \\
6 & Senna alata & $14.62 \pm 1.97$ & $32.06 \pm 2.3$ \\
7 & Tetradenia riparia & $11.55 \pm 3.97$ & $125.31 \pm 10.5$ \\
8 & Gallic acid & $0.71 \pm 0.08$ & $3.21 \pm 0.99$ \\
\hline
\end{tabular}


of Chromolaena odorata, Senna alata, Mitracarpus villosus and Tetradenia riparia. This difference in activity can be explained by the qualitative and quantitative composition in phytochemicals of each extract. Previous studies reported the antioxidant capacities of some of studies plants. Chromolaena odorata was described to be a species with antioxidant capacities related to its flavanone compounds [23]. Phenolic compounds such as astragalin, luteolin and diterpenoids compounds were identified to be responsible of antioxidant activity of $\mathrm{Te}$ tradenia riparia [26]. Certain constituents of Cannabis sativa, in particular cannabinoids are also responsible for this said activity. Cannabidiol (CBD) is a major non-psychotropic phytocannabinoid that attracted a great attention for its therapeutic potential against different pathologies including skin disease by its many beneficial pharmacological effects, including anti-inflammatory and antioxidant effects [27] [28]. The extract from the trunk (red wood) of Pterocarpus soyauxii which proved to be very active after Cannabis sativa had an abundance of phenolic acids far superior to those of the others. Saha et al. (2013) reported the antioxidant capacities of different fraction from the trunk (red wood) of Pterocarpus soyauxii which showed the best radical-scavenging activities [25]. The antioxidant activities of these different parts of the species studied could correlate with their chemical composition. The antioxidant activity could be attributed to polyphenols. Polyphenols represent the most widespread secondary metabolites in the plant kingdom. They have several biological properties including the antioxidant capacities for which they are indicated in the management of various pathologies including skin infectious diseases [29]. The antioxidant potency is one of the most important properties of plant extracts. Since our body may not be producing enough antioxidants, it is necessary to use these antioxidant-rich ones every day to get rid of reactive species and therefore, oxidative stress. Reactive Oxygen Species (ROS) induced by oxidative stress can ultimately lead to apoptotic or necrotic cell death, once accumulated they play a critical role in intrinsic aging and photoaging of human skin in vivo, thus suggested to be responsible for various cancers of the skin and other inflammatory skin disorders [30].

Nowadays, the properties of polyphenols are widely studied in the field of cosmeceuticals where they are recognized as having antibacterial activities, the protective effects on skin aging... [29] [31] [32]. As antioxidants, polyphenols act by various mechanisms which are: the direct trapping of reactives oxygen species (ROS), the inhibition of the enzymes involved in oxidative stress and the chelation of the metallic traces responsible for the production of ROS as well as the protection of systems antioxidant defense [32]. At present, UV irradiation is considered as one of the major threats to the biological populations worldwide. Indeed, it has been identified, that a long-term exposure to the UV radiation can cause pathogenesis of severe conditions on the skin, including photoaging, immunosuppression and skin cancers. Therefore, phenolic compounds from marine and terrestre plants with specially UV inhibition properties and antioxidant properties may have a greater potential to incorporate as an ingredient in cos- 
meceutical products [3] [33].

Radical-scavenging activity is an indicator of the antioxidant activity of the different forms of use in traditional cosmetopoeia of these plant species. To the best of our knowledge, few reports exist on the antioxidant capacities of the red wood of Pterocarpus soyauxii known in DR Congo under the vernacular name of Ngola, whose wood is largely used for skin care (Figure 9), to heal, to color the skin and hair [6]. Given the extent of its wide use in the manufacture of skin care products, further studies are needed, especially on cell models and in vivo to demonstrate its benefit of antioxidant effects on skin pathologies and to enhance its value.

\subsection{Antibacterial Activity}

The results found for the antibacterial activity of studied plants by the microdilution method are presented in Table 4.

The antibacterial activity although null for all plant extracts on Pseudomonas aeruginosa is nevertheless stronger for the extracts of Cannabis sativa on Staphylococcus aureus and Escherichia coli, which correlates with the results obtained by Ali et al. (2012) [34]. Chromolaena odorata and Tetradenia riparia showed a marked effect on Escherichia coli. The antibacterial activity is moderate for Senna alata extract on Escherichia coli. These data are consistent with many previous results of the literature on the assessment of antibacterial activities of these herbal cosmeceutical plants. Omokhua et al. (2017) reported the antibacterial activity of Chromolaena odorata on some bacterial strains and showed that extracts from this plant inhibited the growth of Bacillus subtilis, Bacillus cereus, $S$. aureus and E. coli [35]. Fernandez et al. (2017) showed that Tetradenia riparia was more active on the Gram positive bacteria strains [26]. Cassia alata also showed potential antibacterial effect [36]. Although certain crude extracts from studied botanicals have been shown to be inactive, fractionation studies are needed to determine the active fractions.

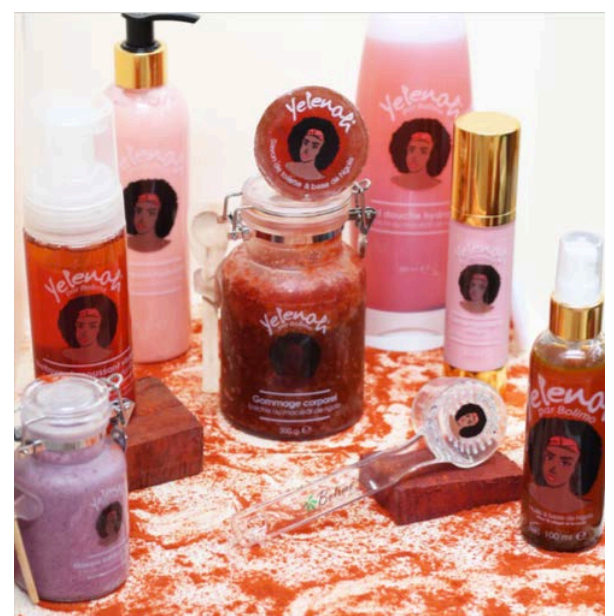

Figure 9. Yelenah ${ }^{\circledast}$ cosmeceuticals products (Range: Facial and body moisturizer, face and body oil, Soap.) manufactured from Pterocarpus soyauxii (Ngola) by Bolimo Sarl. 
Table 4. Minimum inhibitory concentrations MICs $(\mu \mathrm{g} / \mathrm{mL})$ of extracts from plants (data from three experiments in triplicate, MIC defined as the lowest concentration for which no growth was observed in every tested well).

\begin{tabular}{ccccc}
\hline & & \multicolumn{3}{c}{ MIC Values $(\mu \mathrm{g} / \mathrm{mL})$} \\
\cline { 3 - 5 } $\mathrm{N}^{\circ}$ & Plant Extract from & $\begin{array}{c}\text { Staphylococcus } \\
\text { aureus } \\
\text { ATCC25923 }\end{array}$ & $\begin{array}{c}\text { Escherichia coli } \\
\text { ATCC25922 }\end{array}$ & $\begin{array}{c}\text { Pseudomonas } \\
\text { aeruginosa } \\
\text { ATCC9027 }\end{array}$ \\
\hline 1 & Cannabis sativa & 125 & 125 & $>4000$ \\
2 & Chromolaena odorata & $>4000$ & 125 & 4000 \\
3 & Mitracarpus villosus & $>4000$ & $>4000$ & $>4000$ \\
4 & Pterocarpus soyauxii & 4000 & 4000 & $>4000$ \\
5 & Senna alata & 4000 & 500 & $>4000$ \\
\hline
\end{tabular}

$\left.{ }^{*}\right)$ : MIC values below $500 \mu \mathrm{g} / \mathrm{mL}$ : high antibacterial activity; 500 to $1000 \mu \mathrm{g} / \mathrm{mL}$ weak activity and over $1000 \mu \mathrm{g} / \mathrm{mL}$ inactive [19].

Phytochemicals like phenolic compounds, terpenoids present in studied extracts, can act by interacting with the cell membrane or cell wall of microorganisms, leading to changing of the membrane permeability and therefore cell destruction or enter bacterial cells and promote the coagulation of their contents [8] [37]. Therefore, phytochemicals can be used as natural antimicrobial in cosmeceutical plant extracts. Tannins are effectively known to possess interacting antimicrobial activities specifically for skin infectious diseases and diarrhea [19].

\section{Conclusion}

The evaluation of the antioxidant and antibacterial activities of plant extracts of the Congolese Cosmetopoeia has given interesting results. These results corroborate the possible utilization of the different plants' extracts of the studied plant species such as raw material for cosmeceuticals and their compounds as natural preservatives in cosmeceutical formulations instead of synthetic ingredients. However, there are few documents about the chemical and biological studies of Congolese Cosmetopoeia plants. In addition, the scientific validation for the popular use of them deserves to be further investigated because most of the studies to date have only focussed their attention on the Congolese traditional pharmacopeia species and without addressing. The identification and the characterisation of new cosmeceutical active principles from these species would be of great scientific merit. The antioxidant and antibacterial activities of the studied species may have potential therapeutic interest and could justify their use in traditional medicine and local cosmeceutical resources, but further studies are needed, especially in vivo studies, to demonstrate the benefit of these extracts on skincare. 


\section{Acknowledgements}

The authors thank the traditional healer Mubwabwa Gugakedi Don de Dieu for his collaboration.

\section{Conflicts of Interest}

The authors declare no conflicts of interest regarding the publication of this paper.

\section{References}

[1] Soto, M.L., Falqué, E. and Domínguez, H. (2015) Relevance of Natural Phenolics from Grape and Derivative Products in the Formulation of Cosmetics. Cosmetics, 2 , 259-276. https://doi.org/10.3390/cosmetics2030259

[2] Kwan, Y.H., Tung, Y.K., Kochhar, J.S., Li, H., Poh, A.L. and Kang, L. (2014) Handbook of Cosmeceutical Excipients and Their Safeties. Elsevier Science, Amsterdam.

[3] Sanjeewa, K.K.A., Kim, E.A., Son, K.T. and Jeon, Y.J. (2016) Bioactive Properties and Potentials Cosmeceutical Applications of Phlorotannins Isolated from Brown Seaweeds: A Review. Journal of Photochemistry and Photobiology B: Biology, 162, 100-105. https://doi.org/10.1016/j.jphotobiol.2016.06.027

[4] Gao, X.H., Zhang, L., Wei, H. and Chen, H.D. (2008) Efficacy and Safety of Innovative Cosmeceuticals. Clinics in Dermatology, 26, 367-374. https://doi.org/10.1016/j.clindermatol.2008.01.013

[5] Stallings, A.F. and Lupo, M.P. (2009) Practical Uses of Botanicals in Skin Care. Journal of Clinical and Aesthetic Dermatology, 2, 36-40.

[6] Ansel, J., Butaud, J. and Raharivelomanana, P. (2016) Principaux taxons ligneux de la cosmétopée tropicale: Une analyse bibliographique. Comptes Rendus Chimie, 19, 1035-1048. https://doi.org/10.1016/j.crci.2016.03.017

[7] Amuri, K.J. (2014) Contribution à l'inventaire des plantes utilisées dans la cosmetopée congolaise (cas de la route buta). Université de Kisangani, Département d'écologie et Gestion, Faculté des sciences des Ressources Végétales, Travail de fin de Cycle, 9-12.

[8] Ribeiro, A.S., Estanqueiro, M., Oliveira, M.B. and Lobo, J.M.S. (2015) Main Benefits and Applicability of Plant Extracts in Skin Care Products. Cosmetics, 2, 48-65.

https://doi.org/10.3390/cosmetics2020048

[9] Fedoung, E.F., Zra, T., Biyegue, C.F.N., Bissoue, A.N., Baraye, S. and Tsabang, N. (2018) Herbal Cosmetics Knowledge of Arab-choa and Kotoko Ethnic Groups in the Semi-Arid Areas of Far North Cameroon: Ethnobotanical Assessment and Phytochemical Review. Cosmetics, 5, 31. https://doi.org/10.3390/cosmetics5020031

[10] Gould, I.M. (2009) Antibiotics, Skin and Soft Tissue Infection and Meticillin-Resistant Staphylococcus aureus. Cause and Effect. International Journal of Antimicrobial Agents, 34, S8. https://doi.org/10.1016/S0924-8579(09)70542-4

[11] Orchard, A. and Van Vuuren, S. (2017) Commercial Essential Oils as Potential Antimicrobials to Treat Skin Diseases. Evidence-Based Complementary and Alternative Medicine, 2017, Article ID: 4517971. https://doi.org/10.1155/2017/4517971

[12] World Health Organization (2001) World Health Organization: Legal Status of Traditional Medicine and Complementary/Alternative Medicine: A Worldwide Review. WHO/EDM/TRM/2001. 
[13] Latham, P. and Konda ku Mbuta, A.K. (2006) Useful Plants of Bas-Congo Province, Democratic Republic of Congo. 2nd Edition, Mystole Publications, Canterbury, 276.

[14] Konda ku Mbuta, Kabakura, M., Bitengeli, M., Itufa y’okolo, Kavuna, M., Mandanga, M., Kalambayi, M., Izamajole, N., Kazembe, K., Booto, K., Vasaki, N., Mwabonsika, B. and Lody, D. (2012) Plantes medicinales de traditions Province de l'Equateur-R.D. Congo. Institut de Recherche en Sciences de la Santé, 420.

[15] Terashima, H., Kalala, S. and Malasi, N. (1991) Ethnobotany of the Lega in the Tropical Rain Forest of Eastern Zaire: Part One, Zone de Mwenga. African Study Monographs, No. 15, 1-61.

[16] Bahati, L.M., Kapepula, P.M., Kabamba, N.N., Moni, B., Kafuti, G.M., Mungitshi, M., Fundu, T.M., et al. (2017) Microscopic Features, Chromatographic Fingerprints and Antioxidant Property of Some Unconventional Green Leafy Vegetables Consumed in Bandundu, DR Congo. Pharmacognosy Communications, 7, 158-163. https://doi.org/10.5530/pc.2017.4.23

[17] Wagner, H., Bauer, R., Melchart, D., Xioa, P.-G. and Staudinger, A. (2013) Chromatographic Fingerprint Analysis of Herbal Medicinal: Thin-Layer High Performance Liquid Chromatography of Chinese Drugs. Vol. 3, Springer International Publishing, Berlin.

[18] Kapepula, P.M., Ngumbi, P.B., Kawayidiko, M.K., Mpanzu, A.D., Franck, T., Mouithys-Mickalad, A., Tsobo, C.M., et al. (2018) Anti-Inflammatory and Antioxidant Activities of Rungia congoensis, a Traditional Vegetable Consumed by Yombe People from Kongo Central Area (DR. Congo). Natural Product Research, 33, 1650-1654.

[19] Okusa, P.N., Penge, O., Devleeschouwer, M. and Duez, P. (2007) Direct and Indirect Antimicrobial Effects and Antioxidant Activity of Cordia gilletii De Wild (Boraginaceae). Journal of Ethnopharmacology, 112, 476-481. https://doi.org/10.1016/j.jep.2007.04.003

[20] Gurav, S.S. and Gurav, N.S. (2014) Indian Herbal Drug Microscopy. Springer, Berlin. https://doi.org/10.1007/978-1-4614-9515-4

[21] Mukherjee, P.K. (2019) Morphological and Microscopical Evaluations. In: Quality Control and Evaluation of Herbal Drugs, Elsevier, Amsterdam, 151-193. https://doi.org/10.1016/B978-0-12-813374-3.00005-3

[22] Dewi, R., Firza, Y., Nashiry, M.A., Al-sue, F.S.R., Shah, A. and Majid, A. (2019) A Review on Cassia alata: Pharmacological, Traditional and Medicinal Aspects. Aus tralian Herbal Insight, 2, E016-E021. https://doi.org/10.25163/ahi.110005

[23] Putri, D.A. and Fatmawati, S. (2019) A New Flavanone as a Potent Antioxidant Isolated from Chromolaena odorata L. Leaves. Evidence-Based Complementary and Alternative Medicine, 2019, Article ID: 1453612.

https://doi.org/10.1155/2019/1453612

[24] Jato, J., Jato, J.A., Bawa, I. and Onyezili, F.N. (2018) Phytochemical Analysis of Mitracarpus villosus and Comparative Toxicity of Mitracarpus villosus Ointment and Honey. International Journal of Modern Science and Technology, 3, 230-237.

[25] Saha, J.B.T., Abia, D., Dumarçay, S., Ndikontar, M.K., Gérardin, P., Ngamveng Noah, J. and Perrin, D. (2013) Antioxidant Activities, Total Phenolic Contents and Chemical Compositions of Extracts from Four Cameroonian Woods: Padouk (Pterocarpus soyauxii Taubb), Tali (Erythrophleum suaveolens), Moabi (Baillonella toxisperma), and Movingui (Distemonanthus benthamia). Industrial Crops and Products, 41, 71-77. https://doi.org/10.1016/j.indcrop.2012.04.012

[26] Fernandez, A.C.A.M., Rosa, M.F., Fernandez, C.M.M., Bortolucci, W., Melo, U.Z., 
Siqueira, V.L.D., Gazim, Z.C., et al. (2017) Antimicrobial and Antioxidant Activities of the Extract and Fractions of Tetradenia riparia (Hochst.) Codd (Lamiaceae) Leaves from Brazil. Current Microbiology, 74, 1453-1460.

https://doi.org/10.1007/s00284-017-1340-9

[27] Casares, L., García, V., Garrido-Rodríguez, M., Millán, E., Collado, J.A., García-Martín, A., Muñoz, E., et al. (2020) Cannabidiol Induces Antioxidant Pathways in Keratinocytes by Targeting BACH1. Redox Biology, 28, Article ID: 101321. https://doi.org/10.1016/j.redox.2019.101321

[28] Atalay, S., Jarocka-karpowicz, I. and Skrzydlewskas, E. (2020) Antioxidative and Anti-Inflammatory Properties of Cannabidiol. Antioxidants, 9, 21. https://doi.org/10.3390/antiox9010021

[29] Li, A.N., Li, S., Zhang, Y.J., Xu, X.R., Chen, Y.M. and Li, H.B. (2014) Resources and Biological Activities of Natural Polyphenols. Nutrients, 6, 6020-6047. https://doi.org/10.3390/nu6126020

[30] Narendhirakannan, R.T. and Hannah, M.A.C. (2013) Oxidative Stress and Skin Cancer: An Overview. Indian Journal of Clinical Biochemistry, 28, 110-115. https://doi.org/10.1007/s12291-012-0278-8

[31] Daglia, M. (2012) Polyphenols as Antimicrobial Agents. Current Opinion in Biotechnology, 23, 174-181. https://doi.org/10.1016/j.copbio.2011.08.007

[32] Menaa, F., Menaa, A. and Tréton, J. (2014) Polyphenols against Skin Aging. In: Polyphenols in Human Health and Disease, Vol. 1, Academic Press, Cambridge, 819-830. https://doi.org/10.1016/B978-0-12-398456-2.00063-3

[33] Petruk, G., Giudice, R., Del Rigano, M.M. and Monti, D.M. (2018) Antioxidants from Plants Protect against Skin Photoaging. Oxidative Medicine and Cellular Longevity, 2018, Article ID: 1454936. https://doi.org/10.1155/2018/1454936

[34] Ali, E.M.M., Almagboul, A.Z.I., Khogali, S.M.E. and Gergeir, U.M.A. (2012) Antimicrobial Activity of Cannabis sativa L. Chinese Medicine, 3, 61-64. https://doi.org/10.4236/cm.2012.31010

[35] Omokhua, A.G., McGaw, L.J., Chukwujekwu, J.C., Finnie, J.F. and Van Staden, J. (2017) A Comparison of the Antimicrobial Activity and in Vitro Toxicity of a Medicinally Useful Biotype of Invasive Chromolaena odorata (Asteraceae) with a Biotype Not Used in Traditional Medicine. South African Journal of Botany, 108, 200-208. https://doi.org/10.1016/j.sajb.2016.10.017

[36] Oladeji, O.S., Adelowo, F.E., Oluyori, A.P. and Bankole, D.T. (2020) Ethnobotanical Description and Biological Activities of Senna alata. Evidence-Based Complementary and Alternative Medicine, 2020, Article ID: 2580259. https://doi.org/10.1155/2020/2580259

[37] Mahizan, N.A., Yang, S.K., Moo, C.L., Song, A.A.L., Chong, C.M., Chong, C.W., Lai, K.S., et al. (2019) Terpene Derivatives as a Potential Agent against Antimicrobial Resistance (AMR) Pathogens. Molecules, 24, 2631.

https://doi.org/10.3390/molecules24142631 